\title{
Erratum: Phylogenetic analysis of metastatic progression in breast cancer using somatic mutations and copy number aberrations
}

David Brown, Dominiek Smeets, Borbála Székely, Denis Larsimont, A. Marcell Szász, Pierre-Yves Adnet, Françoise Rothé, Ghizlane Rouas, Zsófia I. Nagy, Zsófia Faragó, Anna-Mária Tőkés, Magdolna Dank, Gyöngyvér Szentmártoni, Nóra Udvarhelyi, Gabriele Zoppoli, Lajos Pusztai, Martine Piccart, Janina Kulka, Diether Lambrechts, Christos Sotiriou \& Christine Desmedt

Nature Communications 8:14944 doi: 10.1038/ncomms14944 (2017); Published 21 Apr 2017; Updated 6 Jun 2017

The HTML version of this Article previously published had an incorrect publication date of 20 April 2017; it should have been 21 April 2017. This has now been corrected in the HTML; the PDF version of the paper was correct from the time of publication.

(c) Open Access This article is licensed under a Creative Commons Attribution 4.0 International License, which permits use, sharing, adaptation, distribution and reproduction in any medium or format, as long as you give appropriate credit to the original author(s) and the source, provide a link to the Creative Commons license, and indicate if changes were made. The images or other third party material in this article are included in the article's Creative Commons license, unless indicated otherwise in

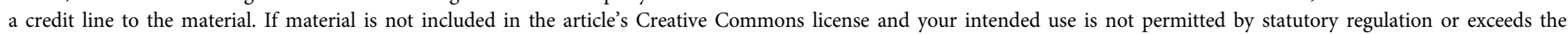
permitted use, you will need to obtain permission directly from the copyright holder. To view a copy of this license, visit http://creativecommons.org/licenses/by/4.0/ 